\title{
PROFIL DISPOSISI MATEMATIS SISWA PEMENANG OLIMPIADE PADA TINGKAT PROVINSI SULA WESI SELATAN
}

\author{
Andi Trisnowali \\ Program Studi Pendidikan Matematika, Program Pascasarjana \\ Universitas Negeri Makassar. Makassar, Indonesia \\ email: anditrisnowali@gmail.com
}

\begin{abstract}
The purpose of this study was to describe the Disposition of Student Mathematical Olympiad winner in South Sulawesi Provincial Level. Subjects of this study there are two people, each of which is a 2 champions and Olympic champion Maths level 4 South Sulawesi province in 2014. The instruments in this study is the researchers themselves as the main instrument guided by students' mathematical disposition questionnaire, and guidelines wawacara. After assessing the data it was concluded that the subject has a positive disposition related to: (1) Interest and curiosity, both subjects happy asking questions and the first subject more enthusiastic than the second subject, (2) Confidence, two subjects challenged with situations-with the situation complicated and retain mathematical ideas, (3) Diligent, both subjects have seriousness in learning and not easily discouraged, (4) Flexible, two subjects often share knowledge and produce a wide range of ideas. The factors that affect the mathematical disposition is the school environment by applying the discipline of the school and the parents who often provide encouragement and motivation to become outstanding students in the field of education.
\end{abstract}

Keywords: Disposition Mathematically, Student Math Olympiad winner.

\begin{abstract}
ABSTRAK
Tujuan penelitian ini adalah untuk mendiskripsikan Disposisi Matematis Siswa pemenang Olimpiade pada Tingkat Provinsi Sulawesi Selatan. Subjek Penelitian ini ada 2 orang yang masing-masing merupakan juara 2 dan juara 4 Olimpiade Matematika tingkat Propinsi Sulawesi Selatan pada tahun 2014. Instrumen dalam penelitian ini adalah peneliti sendiri sebagai instrumen utama yang di pandu oleh angket disposisi matematis siswa, dan pedoman wawacara. Setelah melakukan penafsiran data maka disimpulkan bahwa subjek memiliki disposisi positif terkait : (1) Minat dan Rasa ingin tahu, kedua subjek senang mengajukan pertanyaan dan subjek pertama lebih antusias disbanding subjek kedua, (2) Percaya Diri, kedua subjek tertantang dengan situasi-situasiyang rumit dan mempertahankan gagasan matematika, (3)Tekun, kedua subjek memiliki kesungguhan dalam belajar dan tidak mudah putus asa, (4) Fleksibel, kedua subjek sering berbagi pengetahuan dan menghasilkan berbagai macam ide. Adapun faktor yang mempengaruhi disposisi matematis adalah lingkungan sekolah dengan menerapkan disiplin sekolah serta orang tua yang sering memberikan dorongan maupun motivasi agar menjadi siswa berprestasi didalam bidang pendidikan.
\end{abstract}

Kata Kunci : Disposisi Matematis, Siswa Pemenang Olimpiade Matematika.

\section{PENDAHULUAN}

Usaha-usaha yang intensif dalam meningkatkan kualitas proses dan hasil pendidikan sudah selayaknya lebih diperhatikan, karena melalui pendidikan diyakini akan dapat mendorong mamaksimalkan potensi siswa sebagai sumber daya manusia yang handal unuk dapat bersikap dan berprilaku kritis, kreatif, logis dan inovaif dalam menghadapi serta 
menyelesaikan setiap permasalahan. Mempersiapkan sumber daya manusia yang benar-benar unggul dan dapat diandalkan dalam menghadapi persaingan bebas disegala bidang kehidupan yang kian ketat sebagai akibat globalisasi dunia.

Olimpiade Sains Nasional Tingkat SMP merupakan langkah awal bagi siswa-siswa SMP yang berbakat dan diharapkan terus mengikuti olimpiade di tingkat SMA. Olimpiade Sains Nasional tingkat SMP yang telah dirintis sejak tahun 2003 juga merupakan salah satu wadah strategis untuk merealisasikan paradigma yang telah disebutkan di atas. Pelaksanaan olimpiade secara berkelanjutan akan berdampak positif pada pelaksanaan proses pembelajaran sehingga menjadi lebih kreatif dan inovatif. Pada gilirannya, siswa akan memiliki kesempatan mengembangkan seluruh aspek kepribadian dan kemampuannya melalui pembelajaran yang kreatif, efektif dan menyenangkan.

Bagi para siswa yang mulai menyukai matematika, mereka diberikan kesempatan untuk mengikuti berbagai even kompetisi baik yang diselenggarakan di tingkat kota, wilayah, sampai nasional. Kegiatan ini bertujuan untuk menjajal kemampuan para siswa selain tentunya untuk mencari bibit unggul untuk dipilih menjadi duta pada jenjang kompetisi yang lebih tinggi. Salah satu even yang diharapkan dapat memberikan motivasi bagi para siswa penggemar matematika dan sains adalah diselenggarakannya program Olimpiade Sains Nasional (OSN). Di tingkat SMP, OSN yang telah dirintis sejak tahun 2003 ini yang diprakarsai langsung oleh Direktorat Jendral Pendidikan Dasar dan Menengah.

- Tujuan tersebut dewasa ini lebih dikenal dengan tujuan pendidikan menurut taksonomi bloom yaitu di mana tujuan belajar harus mencangkup tiga ranah: kognitif, afektif serta psikomotorik. Reaksi afektif sebenarnya selalu menjadi bagian yang tidak terpisahkan dengan aspek kognitif seseorang.Saat siswa mengerjakan tugasnya dan mempelajari bagaimana menyelesaikan tugas tersebut mereka secara bersamaan mempelajari apakah mereka suka atau tidak melakukakannya. Siswa mengatasi tugas-tugas sulit dengan lebih efektif ketika mereka menikmati apa yang mereka kerjakan, dan kesuksesan tersebut kemudian membuat mereka gembira dan bangga terhadap dirinya sendiri apalagi kesuksesan tersebut diajang olimpiade
Dalam pembelajaran matematika pembinaan komponen ranah afektif memerlukan kemandirian belajar yang kemudian akan membentuk kecenderungan yang kuat yang dinamakan pula dengan disposisi matematik. Menurut Katz (2009), disposisi adalah kecenderungan untuk secara sadar, teratur, dan sukarela untuk berperilaku tertentu yang mengarah pada pencapaian tujuan tertentu. Dalam konteks matematika, disposisi matematis (mathematical disposition) berkaitan dengan bagaimana siswa memandang dan menyelesaikan masalah; apakah percaya diri, tekun, berminat, dan berpikir fleksibel, dan Menurut Boaler, 1997; Burton, 2004; Povey \& Burton, 2004; Schoenfeld, 1992 (dalam NCTM, 2007) mengakui bahwa disposisi matematis dari orang dewasa dan anak-anak dapat berpengaruh pada lingkungan matematika mereka dan belajar seperti penguasaan konten. Dari penelitian (Gresalfi, 2009) bahwa pengembangan disposisi dapat dipahami sebagai hasil yang dibentuk oleh keterkaitan antara unsur-unsur dari sistem kelas yang mempengaruhi satu sama lain dan siswa yang pada gilirannya dipengaruhi oleh partisipasi siswa itu sendiri. Dengan demikian, disposisi yang memberlakukan siswa tidak hanya kemampuan yang melekat, atau yang dipelajari, melainkan adalah hasil dari kedua dengan kata lain kekuatan kesempatan untuk berpartisipasi. Sedangkan (Sumarmo, 2013) mengatakan bahwa dalam disposisi matematik termuat sikap positif yang mendukung tumbuhnya budi pekerti yaiu sikap kritis, kreatif dan cermat, obyektif dan terbuka, rasa percaya diri, fleksibel, tekun, curiosly, menujukan minat belajar, menilai diri sendiri, berapresiasi terhadap kultur, nilai, dan keindahan matematika, serius dan bergairah dalam belajar, gigih, dan berbagi pendapat dengan orang lain.

Sehingga dari penjelasan tersebut dapat dipahami bahwa disposisi matematis sangat menunjang keberhasilan belajar matematika yang berimplikasi prestasi yang diperolehnya.Siswa memerlukan disposisi matematis untuk bertahan dalam menghadapi masalah, mengambil tanggung jawab dalam belajar, dan mengembangkan kebiasaan kerja yang baik dalam matematika.Karakteristik demikian sangat penting dimiliki siswa khususnya yang mengikuti Olimpiade Matematika. Kelak, siswa belum tentu akan menggunakan semua materi yang mereka pelajari, tetapi dapat dipastikan 
bahwa mereka memerlukan disposisi positif untuk menghadapi situasi problematik dalam kehidupan mereka sehingga pentingnya mengutamakan disposisi matematis siswa dalam mengembangkan kemampuan matematis. Pengutamaan tersebut menjadi semakin penting manakala dihubungkan dengan tuntutan kemajuan IPTEKS dan suasana bersaing yang semakin ketat terhadap lulusan semua jenjang pendidikan.

Berdasarkan penjelasan diatas, maka penulis mengemukakan pertanyaan penelitian sebagai berikut:

1. Bagaimanakah profil disposisi matematis siswa pemenang olimpiade pada tingkat Provinsi Sulawesi Selatan?

2. Faktor apa saja yang mempengaruhi disposisi matematis siswa pemenang olimpiade pada tingkat Provinsi Sulawesi Selatan?

Salah satu faktor yang mempengaruhi proses dan hasil belajar matematika siswa adalah disposisi mereka terhadap matematika. Apa itu disposisi? Katz (2009) mendefinisikan disposisi sebagai kecenderungan untuk berperilaku secara sadar (consciously), teratur (frequently), dan sukarela (voluntary) untuk mencapai tujuan tertentu.Perilaku-perilaku tersebut diantaranya adalah percaya diri, gigih, ingin tahu, dan berpikir fleksibel.

Dalam konteks matematika, menurut Katz (2009), disposisi matematis (mathematical disposition) berkaitan dengan bagaimana siswa menyelesaikan masalah matematis; apakah percaya diri, tekun, berminat, dan berpikir fleksibel untuk mengeksplorasi berbagai alternatif penyelesaian masalah.Dalam konteks pembelajaran, disposisi matematis berkaitan dengan bagaimana siswa bertanya, menjawab pertanyaan, mengkomunikasikan ide-ide matematis, bekerja dalam kelompok, dan menyelesaikan masalah.

Polking (1998), mengemukakan bahwa disposisi matematika menunjukkan (1) rasa percaya diri dalam menggunakan matematika, memecahkan masalah, memberikan alasan mengkomunikasikan gagasan, (2) fleksibilitas dalam menyelediki gagasan matematik dan berusaha mencari metode alternative dalam memecahkan masalah, (3) tekun mengerjakan tugas matematika, (4) minat, rasa ingin tahu (curiousity), dan daya temu dalam melaksanakan tugas matematika.
Menurut Pearson Education (2000), disposisi matematis mencakup minat yang sungguh-sungguh (genuine interest) dalam belajar matematika, kegigihan untuk menemukan solusi masalah, kemauan untuk menemukan solusi atau strategi alternatif, dan apresiasi terhadap matematika dan aplikasinya pada berbagai bidang. Menurut NCTM (Pearson Education, 2000), disposisi matematis mencakup kemauan untuk mengambil risiko dan mengeksplorasi solusi masalah yang beragam, kegigihan untuk menyelesaikan masalah yang menantang, mengambil tanggung jawab untuk merefleksi pada hasil kerja, mengapresiasi kekuatan komunikasi dari bahasa matematika, kemauan untuk bertanya dan mengajukan ide-ide matematis lainya, kemauan untuk mencoba cara berbeda untuk mengeksplorasi konsep-konsep matematis, memiliki kepercayaan diri terhadap kemampuannya, dan memandang masalah sebagai tantangan.

Sejalan dengan hal di atas wardani (Sumarmo, 2013) mendefinisikan disposisi matematis adalah ketertarikan dan apresiasi terhadap matematika yaitu kecendrungan untuk berpikir dan bertindak dengan positif, termasuk kepercayaan diri, keingintahuan, ketekunan, antusias dalam belajar, gigih menghadapi permasalahan, fleksibel, mau berbagi dengan orang lain. Sedangkan menurut (Mulyana, 2009) disposisi terhadap matematika adalah perubahan kecendrungan siswa dalam memandang dan bersikap terhadap matematika, serta bertindak ketika belajar matematika. Misalnya, ketika siswa dapat menyelesaikan permasalahan non rutin, sikap dan keyakinannya sebagai seorang pelajar menjadi lebih positif. Makin banyak konsep matematika dipahami, makin yakinlah bahwa matematika itu dapat dikuasainya.

Menurut silver (dalam sumarmo, 2013) menguraikan disposisi matematik ke dalam beberapa komponen yaitu: rasa percaya diri (self confident), rasa diri mampu (self efficacy), rasa ingin tahu (curiousity), senang mengerjakan tugas matematik, rajin dan tekun (diligence). Rasa percaya diri (self confident), dan rasa diri mampu (self efficacy) adalah sikap positif yang merupakan bagian penting dalam pembelajaran rasa percaya diri sedangkan sikap positif ditunjukan dengan semangat belajar, penuh perhatian, saling sumbang saran dan saling menghormati terhadap sesama sebaliknya sikap 
negative ditunjukkan dengan rasa tidak suka, tidak tertarik, tidak berminat dan cemas terhadap matematik.

NCTM (dalam Sumarmo, 2013) menjelaskan bahwa

...Disposisition can be assessed by using observation on students' acivity during discussion, solving problem, doing their individual tasks, and presenting students' work in small group discussion, or by using disposition scale"

Menurut

(Maxwell,2001),disposisi terdiri dari (1)

inclination (kecenderungan), yaitu bagaimana sikap siswa terhadap tugas-tugas; (2) sensitivity (kepekaan), yaitu bagaimana kesiapan siswa dalam menghadapi tugas; dan (3) ability (kemampuan), yaitu bagaimana siswa fokus untuk menyelesaikan tugas secara lengkap; dan (4) enjoyment (kesenangan), yaitu bagaimana tingkah laku siswa dalam menyelesaikan tugas.

Disposisi matematis siswa dikatakan baik jika siswa tersebut menyukai masalahmasalah yang merupakan tantangan serta melibatkan dirinya secara langsung dalam menemukan/menyelesaikan masalah. Selain itu siswa merasakan dirinya mengalami proses belajar saat menyelesaikan tantangan tersebut. Dalam prosesnya siswa merasakan munculnya kepercayaan diri, pengharapan dan kesadaran yang positif.

Menurut Carr (dalam Maxwell, 2001), disposisi dan kemampuan adalah dua hal yang berbeda.Seorang siswa mungkin saja menunjukkan disposisi matematis tinggi, tetapi tidak memiliki cukup pengetahuan atau kemampuan terkait substansi materi. Meski demikian, bila ada dua siswa yang mempunyai potensi kemampuan sama, tetapi memiliki disposisi berbeda, diyakini akan menunjukkan kemampuan yang berbeda. Siswa yang memiliki disposisi tinggi akan lebih gigih, tekun, dan berminat untuk mengeksplorasi hal-hal baru. Hal ini memungkinkan siswa tersebut memiliki pengetahuan lebih dibandingkan siswa yang tidak menunjukkan perilaku demikian.Pengetahuan inilah yang menyebabkan siswa memiliki kemampuan-kemampuan tertentu.

(Slameto, 2010) percaya bahwa latar belakang budaya, lingkungan rumah tangga dan status social-ekonomi, orang tua tentang anak- anak dan mereka belajar matematika dan keyakinan sendiri tentang matematika semua mempengaruhi cara siswa memahami dan belajar matematika. Orang tua biasanya menginginkan anaknya mencapai prestasi yang sangat baik sehingga dari bimbingan orang tua memengang peranan yang penting anak/siswa yang mengalami kesulitan dalam mengerjakan tugas dirumah dapat ditolong dengan memberikan bimbingan belajar yang sebaik-baiknya, tentu saja keterlibatan orang tua akan sangat mempengaruhi keberhasilan bimbingan tersebut. Suasana atau lingkungan belajar merupakan situasi tempat berlangsungya belajar siswa, serta mengembangkan daya dan disposisi matematik siswa.

Berdasarkan pertanyaan penelitian yang dikemukakan di atas, maka penelitian ini bertujuan :

1. Menjelaskan profil diposisi matematis siswa pemenang olimpiade pada tingkat Provinsi Sulawesi Selatan

2. Menjelaskan faktor apa saja yang mempengaruhi disposisi matematis siswa pemenang olimpiade pada tingkat Provinsi Sulawesi Selatan

\section{METODE PENELITIAN}

Penelitian ini merupakan penelitian eksploratif dengan pendekatan kualitatif.yang bertujuan untuk menjelaskan secara faktual mengenai disposisi matematis siswa pemenang olimpiade pada tingkat provinsi Sulawesi selatan. Fokus penelitian diberikan agar menghindari kesalahpahaman dalam penelitian ini:

1. Profil disposisi matematis yang dimaksud dalam penelitian ini adalah gambaran secara faktual yang terstruktur tentang disposisi matematis siswa.

2. Disposisi matematis siswa dalam penelitian ini adalah sikap positif yang terdiri dari beberapa aspek, dari aspek tersebut memiliki indikator masing-masing yang dapat diukur pada disposisi matematis siswa sebagai berikut:

a. Kepercayaan diri dengan indikator percaya diri yaitu

1) Mengatasi masalah matematika yang sulit

2) Tertantang dengan situasi-situasi yang rumit dan tidak cenderung mencari jalan tergampang terhadap matematika 
3) Menyelesaikan masalah matematika tanpa bantuan dari orang lain dan tidak mudah dipengaruhi oleh orang lain

4) Tidak takut gagal dan berani mempertahankan gagasan terhadap matematika

b. Minat dan Rasa ingin tahu dengan indikator yaitu:

1) Sering mengajukan pertanyaan

2) Berusaha keras dalam belajar, banyak membaca/menjajaki bukubuku untuk mencari gagasan baru

3) Terdorong untuk mengetahui lebih banyak tentang matematika dan mencari jawaban yang sulit dari pada yang mudah

c. Tekun dengan indikator yaitu:

1) Kesungguhan dalam belajar

2) Tekun dalam mengerjakan tugas

3) Tidak cepat putus asa dalam mencapai tujuan

d. Flesibilitas yang dengan indikator yaitu:

1) Menemukan dan menghasilkan berbagai macam ide, jawaban dan pertanyaan yang bervariasi

2) Kerjasama/berbagi pengetahuan

3) Menghargai pendapat yang berbeda

Penelitian ini dilaksanakan di Propinsi Sulawesi Selatan yaitu di Kota Makassar. Subjek penelitian ditentukan berdasarkan hasil seleksi Olimpiade Matematika tingkat SMP tahun 2014, subjek dipilih dengan cara purposive langsung yaitu peringkat 2 dan peringkat 4 dalam olimpiade matematika pada tingkat provinsi Sulawesi Selatan dengan alasan bahwa peringkat 2 berasal dari sekolah negeri dan peringkat 4 berasal dari sekolah swasta. Selain kedua subjek, kerabat seperti orangtua, guru dan sahabat yang dimintai keterangan

Subjek yang berasal dari sekolah negeri merupakan keluarga dengan keadaan ekonomi yang cukup dan memiliki hubungan yang cukup dekat dengan orang tua dan saudara-saudaranya yang terlebih dahulu berhasil sampai sekarang, sehingga subjek ini sering diberikan motivasi kepada orang tua untuk tetap selalu belajar dan berprestasi seperti saudara-saudaranya, orang tua subjek memfasilitasi tiga tempat bimbingan belajar yang bagus demi keberhasilan subjek, subjek menghabiskan waktunya untuk belajar dengan mengikuti bimbingan belajar tersebut dan dalam lingkungan sekolah subjek ditempatkan pada kelas khusus yaitu kelas bakat khusus dimana didalamnya terdapat siswa-siswa yang memiliki bakat khusus termasuk subjek yang memiliki bakat khusus dibidang matematika dan dalam pembelajaran dikelas khususnya subjek sering menggantikan gurunya seolah sebagai guru matematika. Sedangkan subjek yang sekolah di swasta memiliki keadaan ekonomi yang lebih dibanding subjek yang sekolah di negeri, subjek hanya memiliki satu saudara dan masih sekolah dibangku SD, subjek tidak begitu dekat dengan orang tua dikarenakan kesibukan orang tuanya sebagai dokter spesialis yang lebih banyak menghabiskan waktunya di tempat kerja, sehingga orang tua subjek memberikan tanggung jawab penuh dari sekolahnya dalam hal belajar, sehingga subjek menghabiskan banyak waktu belajarnya disekolah dengan mengikuti bimbingan-bimbingan belajar dan mengikuti karantina bimbingan belajar khusus disekolah. Kedua subjek sejak di SD sampai sekarang SMP sangat sering mengikuti dalam hal ajang lombalomba olimpiade baik tingkat kampus maupun olimpiade sains nasional dibidang yang sama yaitu bidang matemtika.

Instrumen utama dalam penelitian ini adalah peneliti sendiri.Dalam hal ini peneliti merupakan perencana, pelaksana pengumpul data, penganalisis, penafsir data, dan menjadi pelapor hasil penelitian. Peneliti sebagai instrumen akan mempermudah menggali informasi yang menarik meliputi informasi lain dari yang lain (temuan-temuan yang menarik), yang tidak direncanakan sebelumnya, yang tidak terduga terlebih dahulu atau yang tidak lazim terjadi. Pada penelitian ini juga digunakan instrumen pendukung lainnya yaitu angket disposisi matematis dan pedoman wawancara.

Sebelum digunakan, instrumen penelitian yang disusun ditelaah atau dinilai oleh ahli, yaitu dosen pendidikan matematika yang bergelar doktor atau sedang menempuh pendidikan doktor pendidikan matematika, terkait validitas muka dan validitas isi instrumen ini. Validitas muka mencakup aspek-aspek (1) kejelasan dan kekomunikatifan bahasa yang digunakan dan (2) kemenarikan penampilan sajian instrumen. Sedangkan validitas isi mencakup kesesuaian butir-butir instrumen dengan aspek-aspek disposisi matematis.

Berikut diuraikan masing-masing hasil validasi instrumen penelitian ini 


\section{Angket disposisi matematis}

Angket disposisi matematis digunakan untuk mengukur disposisi matematis siswa yang mencakup aspek-aspek (1) kepercayaan diri, (2) minat dan keingintahuan (3) ketekunan dan, (4) fleksibilitas. Angket disposisi matematis ini terdiri atas 28 pernyataan dengan 4 kategori respon, yaitu Sangat Setuju (SS), Setuju (S), Tidak Setuju (TS), dan Sangat Tidak Setuju (STS). Angket tersebut diperoleh dengan dikembangkan oleh peneliti, dengan berdasarkan pada indikator-indikator yang ada pada tinjauan pustaka, untuk mendapatkan angket disposisi sebagaimana yang telah disebutkan maka dilakukan validasi isi dan konstruk oleh dua orang pakar di bidang pendidikan matematika. Lampiran $\mathrm{C}$ menunjukkan bahwa angket disposisi matematis memenuhi validasi isi dan konstruk. Saran perbaikan berkaitan dengan pernyataan-pernyataan dalam angket disposisi matematis mencakup semua indikator yang dicapai disposisi siswa serta penggunaan bahasa sesuai kaidah bahasa indonesia dengan menggunakan bahasa yang efektif, serta pernyataan yang bermakna jelas.

2. Pedoman Wawancara

Penggalian data melalui wawancara dilakukan dengan penggabungan wawancara terstruktur dan tak terstruktur. Wawancara terstruktur adalah wawancara yang pewawancaranya menetapkan sendiri masalah dan pertanyaan-pertanyaan yang akan diajukan dengan harapan dapat mencari jawaban terhadap dugaan. Selanjutnya untuk menemukan informasi yang tidak baku dan untuk lebih mendalami suatu masalah perlu menekankan pada penyimpangan, penafsiran yang tidak lazim, penafsiran kembali, maka dilakukan dengan wawancara yang tidak terstruktur. Pada wawancara tidak struktur, pertanyaan tidak disusun terlebih dahulu tetapi disesuaikan dengan keadaan dan ciri yang unik dari responden. Untuk mendapatkan informasi sesuai tujuan penelitian, maka pengembangan pedoman wawancara mengacu pada ketentuan: (1) pertanyaan yang diajukan tidak menyebutkan secara langsung indikator penelitian, (2) pertanyaan yang diajukan bersifat terbuka. Misalnya, "ceritakan kepada saya apa yang ada dalam pikiranmu saat ini!", (3) pertanyaan yang diajukan disesuaikan dengan respon subjek berupa tulisan atau penjelasan, (4) jika respon subjek terhadap pertanyaan yang diajukan tidak sesuai dengan tujuan penelitian dan menurut analisis peneliti, respon yang diberikan tidak menarik untuk diungkapkan, maka diajukan pertanyaan dengan kalimat yang berbeda, namun tetap dalam inti permasalahan. Namun, jika respon yang diberikan oleh subjek menarik untuk diungkapkan, meskipun tidak sesuai dengan tujuan penelitian, maka peneliti mengajukan pertanyaan bersifat menggali. Hal ini dilakukan untuk mendapatkan informasi yang dapat dijadikan temuan menarik atau verifikasi data, (5) pertanyaan yang diajukan bersifat menggali dan menghindari sifat menuntun. Untuk mendapatkan pedoman wawancara sebagaimana yang telah disebutkan maka dilakukan validasi isi dan konstruk oleh dua orang pakar di bidang pendidikan matematika. Lampiran C menunjukkan bahwa pedoman wawancara memenuhi validasi isi dan konstruk. Saran perbaikan berkaitan dengan pertanyaanpertanyaan dalam pedoman wawancara harus lebih spesifik untuk dapat mengungkap indikator dari disposisi siswa serta penggunaan bahasa yang mudah dipahami oleh siswa

Miles and Huberman (Sugiyono, 2012) mengemukakan bahwa aktivitas dalam analisis data penelitian kualitatif dilakukan secara interaktif dan berlangsung secara terus menerus sampai tuntas, sehingga datanya sudah jenuh.

Proses analisis data dimulai sejak pengumpulan data sampai pada saat peneliti menyelesaikan tugas di lapangan. Ketika peneliti mulai mengumpulkan data, analisis dilakukan terhadap pertanyaan yang diajukan berdasarkan respon subjek.Misalkan, jika respon subjek terhadap pertanyaan yang diajukan tidak sesuai dengan tujuan penelitian dan menurut analisis peneliti, respon yang diberikan tidak menarik untuk diungkapkan, maka diajukan pertanyaan dengan kalimat yang berbeda, namun tetap dalam inti permasalahan.Tetapi, jika respon subjek menarik untuk diungkap, meskipun tidak sesuai dengan tujuan penelitian, maka peneliti mengajukan pertanyaan yang sifatnya menggali.Data yang telah terkumpul dan masih dalam bentuk rekaman, selanjutnya ditransformasi ke dalam bentuk transkrip wawancara.

Telah dikemukakan bahwa data dalam penelitian ini berupa transkrip hasil wawancara pada setiap subjek penelitian. Untuk menganalisis data dilakukan dengan menggunakan analisis isi kualitatif (qualitatif content analysis) dengan pendekatan deduktif (Elo \& 
Kyngas, 2007) dimana langkah-langkahnya sebagai berikut :

\section{Tahap persiapan (Preparation phase)}

Tahap persiapan dimulai dengan pengumpulan data kemudian memilih unit analisis. Unit analisis mengacu pada berbagai macam objek studi misalnya orang, program, sebuah organisasi dan lainnya (Graneheim \& Lundman, 2003). Unit analisis dalam penelitian ini adalah siswa beserta dengan keseluruhan transkrip wawancara. Langkah selanjutnya yaitu menyusun transkrip dari hasil wawancara dengan subjek penelitian kemudian dalam proses analisis, peneliti berusaha untuk memahami data secara keseluruhan.

\section{Tahap pengorganisasian (Organising phase)}

a) Mengembangkan matriks analisis (Developing analysis matrice)

(1) Menentukan unit makna yaitu konstelasi kata-kata atau pernyataan yang terkait dengan makna sentral yang sama. Unit makna dapat berupa kata-kata, kalimat atau paragraf yang mengandung aspek yang berhubungan satu sama lain melalui konten dan konteks mereka.

(2) Menentukan unit makna kondensasi yaitu mengacu pada proses memperpendek sambil tetap mempertahankan inti.

b) Mengumpulkan data berdasarkan content

c) Menentukan kategori. Dalam penelitian ini, kategori merujuk pada komponen/ indikator disposisi matematis siswa yang dianggap sama dengan sub tema. Untuk selanjutnya dalam penelitian ini menggunakan subtema.

d) Proses abstraksi

3. Melaporkan/memaparkan data dan hasil analisis

Untuk memudahkan peneliti dalam memaparkan data hasil penelitian maka dibuat Coding dan dilakukan pengkodean pada petikan jawaban subjek pada saat wawancara yang bertujuan untuk memudahkan pemaparan data profil disposisi siswa pemenang olimpiade matematika, maka dilakukan coding pada petikan jawaban subjek penelitian saat wawancara.

\section{HASIL DAN PEMBAHASAN}

\section{Hasil}

\section{Hasil Analisis isi Disposisi Minat dan Rasa ingin tahu Siswa}

Subjek sangat senang dan bangga sekali mengetahui suatu masalah matematika yang tidak diketahui oleh orang lain dan membantu orang lain mengetahui masalah matematika. Selain menggali lebih banyak informasiinformasi melalui buku-buku matematika diluar sekolah juga menggali informasi melalui internet untuk mengetahui sejarah matematika karena subjek menganggap internet itu adalah jendela dimana disimpulkan bahwa subjek ini selalu terdorong untuk mengetahui lebih banyak dan juga menjajaki media social untuk mendapatkan gagasan baru yang sesuai dengan indicator rasa ingin tahu pada disposisi matematis siswa. Selain itu subjek juga selalu mengajukan pertanyaan tentang suatu masalah matematika pada saat pembelajaran tidak hanya memperhatikan dan mencatat saat guru menjelaskan atau menerangkan dikelas, meskipun masalah tersebut dia sudah pahami ataupun belum dipahami. Kemudian dia lebih tertarik menyelesaikan yang lebih sulit atau lebih rumit dari pada yang mudah sehingga subjek merasa bahwa hanya dia yang bisa menyelesaikan masalah tersebut dan menjadi yang terbaik dan dia juga memperlihatkan usaha kerasnya dalam pembelajaran jika guru matematikanya berhalangan masuk mengajar dikelas maka subjek ini tetap belajar dikelas dan mengerjakan soal-soal yang ada dibuku matematika selain itu dia menjelajahi media social internet untuk mendapatkan masalah-masalah matematika yang lebih rumit untuk diselesaikan serta mencari referensi soalsoal matematika yang sulit dan menantang seperti soal-soal olimpiade untuk dikerjakan dan diselesaikan seorang diri.

\section{Hasil Analisis isi Disposisi Minat dan Rasa ingin tahu Siswa dan teman}

Subjek sering mengajukan pertanyaanpertanyaan kepada guru baik yang belum dan yang sudah dimengerti. Selain itu dia senang menjajaki buku-buku untuk mencari gagasangagasan baru dengan membawa buku-buku lain selain buku sekolah dan selalu terdorong untuk mengetahui lebih banyak lagi sehingga sering kali mengetahui masalah matematika yang tidak diketahui oleh orang lain. Juga dia memiliki 
usaha yang sangat keras dan minat yang baik karena jika guru berhalangan masuk maka dia berusaha membaca buku matematika dan sering berlatih mengerjakan soal-soal yang ada dibuku tersebut sehingga dia butuh konsentrasi tinggi dan latihan-latihan yang banyak. Selain itu dia juga sangat sering menyelesaikan masalahmasalah berkategori yang sangat sulit sehingga dia lebih mementingkan menyelesaikan masalahmasalah yang sulit dibanding masalah-masalah yang mudah dengan memanfaatkan media social seperti internet dalam menyelesaikan masalah dan mencari-cari rumus yang dia tidak ketahui selain itu juga dia biasa melihat-lihat contohcontoh soal untuk memperkaya dan menambah referensi dan sering sekali membuka internet dikelas dan berlatih soal-soal olimpiade matematika.

\section{Hasil Analisis isi Disposisi Minat dan Rasa ingin tahu Siswa dan Guru}

Subjek sangat serius memperhatikan dalam belajarnya dan sangat sering mengajukan pertanyaan pada masalah matematika yang kurang jelas dan yang belum maupun sudah dia pahami untuk memperkaya gagasan sendiri. Selain itu dia belajar dengan menggunakan bukubuku selain buku sekolah dan juga menambah referensi dengan memanfaatkan media social internet. Dia sangat senang menjajaki buku maupun internet untuk mendapatkan gagasan baru sehingga dia selalu terdorong mengetahui lebih banyak dari orang lain dan mengetahui masalah matematika yang tidak diketahui oleh orang lain.

\section{Hasil Analisis isi Disposisi Minat dan Rasa ingin tahu Siswa dan Orang Tua}

Subjek berusaha sering memanfaatkan media social seperti internet untuk menyelesaikan masalah-masalah matematika selain itu dia terdorong menyelesaikan tugastugas dan sangat tekun mengerjakan tugas dirumah secara mandiri bahkan dia cenderung resah apabila belum menyelesaikan masalah matematika dirumah. Ketekunan subjek sangat baik. Dia memiliki kesungguhan dalam belajar yang kuat dengan mengikuti bimbinganbimbingan belajar matematika diluar sekolah dengan keinginan sendiri dan dorongan dari orang tua sehingga dari bimbingan tersebut dia sering mengikuti lomba-lomba olimpiade matematika, dari lomba tersebut meskipun dia gagal berkali-kali dia tidak cepat putus asa dalam mencapai hasil yang maksimal dalam mencapai tujuan.

\section{Pembahasan}

Pada bagian ini dibahas keterkaitan dari hasil penelitian dengan teori-teori yang relevan atau pendapat-pendapat para ahli yang sesuai dengan penelitian ini yaitu disposisi matematis (mathematical disposition) menurut Katz (2009) bahwa disposisi matematis berkaitan dengan bagaimana siswa menyelesaikan masalah matematis apakah dia percaya diri, tekun, berminat dan berfikir fleksibel. Dari hasil penelitian ini dilihat dari minat dan rasa ingin tahu kedua subjek cenderung sama dimana kedua subjek tertarik mengetahui suatu masalah matematika yang tidak diketahui oleh orang lain, dan menggali lebih banyak informasi-informasi melalui buku dan internet untuk mengeksplorasi hal-hal yang baru sejalan yang di kemukakan oleh (Ardiyanto, 2013) bahwa munculnya rasa ingin tahu dalam matematika akan mengakibatkan seseorang terus belajar sehingga terus berupaya menggali informasi-informasi terkait dengan lingkungannya sehingga menjadi kaya akan wawasan dan carr (dalam Maxwell, 2001) menyatakan bahwa siswa yang memiliki disposisi tinggi akan lebih tekun dan berminat untuk mengeksplorasi hal-hal baru. Kedua subjek cenderung mengajukan banyak pertanyaan, kemudian tertarik menyelesaikan masalah-masalah yang menantang seperti masalah yang lebih sulit atau lebih rumit dari pada yang mudah sesuai yang di jelaskan oleh NCTM (Pearson Education, 2000) bahwa disposisi matematis mencakup kamauan untuk mengambil resiko dan mengeksplorasi solusi masalah yang beragam dan kegigihan untuk menyelesaikan masalah yang menantang.

Dari segi aspek percaya diri kedua subjek cenderung sama menunjukkan bahwa kedua subjek menyelesaikan masalah yang tidak diketahui orang lain dan mencoba memaparkan didepan kelas sebagai guru dan menyelesaikan masalah yang tidak sama dengan yang biasa diberikan dan menyelesaikan masalah sesuai dengan pemikiran sendiri dan juga selalu optimis dengan kebenaran jawaban dalam menyelesaikan masalah matematika meskipun masalah tersebut masalah yang sangat sulit (martyanti, 2012) menurut Ghuron dan Risnawita, S. bahwa self 
confidence adalah keyakinan bahwa seseorang mampu menanggulangi suatu masalah dengan situasi terbaik dan dapat memberikan sesuatu yang menyenangkan bagi orang lain. Karena kedua subjek menyukai dan terdorong untuk mengatasi masalah-masalah yang sulit dan merasa tertantang oleh situasi-situasi yang rumit, tertarik pada tugas-tugas yang sulit dan mencari penyelesaian tanpa bantuan orang lain sehingga tidak mudah dipengaruhi oleh orang lain ini sejalan yang dikemukakan oleh (Maxwell, 2001) disposisi matematis siswa dikatakan baik jika siswa tersebut menyukai masalah-masalah yang merupakan tantangan serta melibatkan dirinya secara langsung dalam menemukan/menyelesaikan masalah sehingga dalam prosesnya siswa merasakan munculnya kepercayaan diri, pengharapan dan kesadaran yang positif terkait juga yang di kemukakan oleh (Pearson education, 2000) memiliki kepercayaan diri terhadap kemampuannya, dan memandang masalah sebagai tantangan. Untuk aspek yang ketiga yaitu ketekunan dimana kedua subjek ini memiliki kesamaan dan perbedaan masingmasing berdasarkan hasil penelitian menunjukkan bahwa kedua subjek menyelesaikan masalah-masalah matematika yang ada dibuku sebelum disuruh atau diperintahkan oleh guru untuk diselesaikan dan juga kedua subjek sangat terdorong menyelesaikan tugas-tugas matematika terkait yang dikemukakan oleh (polking, 1998) yang menyatakan bahwa disposisi matematis menunjukkan salah satunya adalah ketekunan mengerjakan tugas dan juga menurut (Maxwell, 2001) bagaimana sikap siswa terhadap tugas, kesiapan dalam menghadapi tugas, menyelesaikan tugas secara lengkap dan tingkah laku siswa dalam menyelesaikan tugas, hal yang berbeda dari kedua subjek adalah subjek pertama cenderung mengeluh dan merasa bersalah jika belum menyelesaikan masalah atau tugas dirumah dan cenderung terdorong menyelesaikan tugas dan belajar mandiri dirumah sedangkan untuk subjek kedua sebaliknya dia tidak pernah merasa mengeluh dan cenderung tidak resah dalam menyelesaikan masalah dirumah karena subjek lebih tertarik menyelesaikan masalahmasalah disekolah dan tidak membawanya kerumah.

Dari segi fleksibel bahwa kedua subjek ini menunjukkan bahwa, jika diberi masalah matematika dia memiliki lebih dari satu cara penyelesaian dan juga subjek sering menjawab soal dengan berbagai macam penyelesaian atau bervariasi dan jawaban itu cenderung singkat dan lebih efektif sejalan yang dikemukakan oleh (Katz, 2009) yang menyatakan bahwa disposisi matematis (mathematical disposition) berkaitan dengan bagaimana siswa berfikir fleksibel untuk mengeksplorasi berbagai alternative penyelesaian masalah, bekerja dalam kelompok dan menurut (Polking, 1998) menyatakan bahwa fleksibilitas dalam menyelidiki gagasan matematik dan berusaha mencari metode alternative dalam memecahkan masalah sejalan yang dipikirkan wilson (Kusumaningrum \& Saefudin, 2012) yaitu kemampuan untuk memproduksi atau menghasilkan suatu produk, persepsi atau ide yang bervariasi terhadap masalah. Selain itu kedua subjek mendiskusikan masalah sering sekali memiliki tanggapan yang selalu berbeda tetapi juga tidak menyalahkan tanggapan orang lain dan subjek cenderung memberikan kesempatan untuk mengemukakan pendapat orang lain lalu mengambil keputusan yang benar sesuai yang dijelaskan oleh Wardani (Sumarmo, 2013) bahwa mendefinisikan disposisi matematis adalah kecenderungan untuk bertindak positif dan mau berbagi dengan orang lain dan juga menurut silver (dalam Sumarmo, 2013) penuh perhatian, saling sumbang saran dan saling menghormati terhadap sesama.

Selain itu kedua subjek ini sangat memiliki kesungguhan dalam belajar perlu diketahui bahwa dia selalu ingin mengikuti bimbingan belajar disekolah maupun diluar sekolah hanya saja yang membedakan bahwa subjek pertama lebih dominan melakukan bimbingan belajar di luar sekolah karena dilingkungan sekolah subjek pertama tidak difasilitasi untuk mengadakan bimbingan belajar khusus matematika sehingga subjek memiliki keinginan besar untuk mengikuti bimbingan belajar diluar sekolah untuk menambah kemampuannya dan juga ikut serta dalam bimbingan olimpiade karena subjek memiliki keinginan besar mengikuti dalam hal bimbingan belajar serta berkeinginan menjadi siswa yang paling cerdas matematika selain itu juga subjek sangat didukung oleh orang tua yang menginginkan anaknya mencapai prestasi yang sangat baik sehingga diberikan dorongan dan memotivasi subjek agar supaya menjadi siswa yang berprestasi berbeda dengan subjek kedua dimana subjek lebih dominan mengikuti bimbingan yang memang sudah disiapkan dan 
difasilitasi di lingkungan sekolah dan sangat menunjang keberhasilan siswa terlebih lagi dalam hal bimbingan khusus olimpiade yang memang bimbingan tersebut dikarantinakan dan selain itu juga subjek bisa berprestasi juga karena lingkungan keluarga terutama orang tua yang sering memberikan semangat dan motivasi positif terhadap subjek sejalan yang di kemukakan oleh Raymond and Barton (Slameto, 2010), keduanya percaya bahwa latar belakang budaya, lingkungan rumah tangga, status socialekonomi dan orang tua mempengaruhi cara siswa memahami dalam belajar matematika dan juga tentu saja keterlibatan orang tua akan sangat mempengaruhi keberhasilan bimbingan tersebut.

\section{SIMPULAN DAN SARAN}

Berdasarkan hasil anaslis data yang mengacu pertanyaan penelitian, maka hasil penelitian dapat disimpulkan sebagai berikut: Disposisi Matematis Siswa terdiri dari beberapa aspek :

Aspek Minat dan Rasa Ingin Tahu, subjek senang mengajukan pertanyaan yang menantang, memiliki dorongan untuk selalu mencari informasi-informasi baru melalui buku-buku sekolah maupun luar sekolah selain buku-buku juga senang mencari informasi baru melalui internet, senang mancari jawaban yang variatif dari suatu masalah matematika yang dihadapi, senang menyelesaikan masalah-masalah matematika yang menantang, senang meluangkan waktu untuk mempelajari matematika.

Aspek Percaya Diri,subjek tertantang untuk mengatasi masalah-masalah matematika yang sulit, sangat yakin bisa menyelesaikan masalah-masalah matematika yang memiliki kategori yang rumit/sulit, yakin memiliki kemampuan matematika lebih tinggi, bangga menyelesaikan masalah matematika tanpa bantuan dari orang lain, yakin dengan alternative penyelesaiaan yang diperoleh, bangga menyelesaikan masalah matematika hingga mencapai hasil maksimal, berani mempertahankan gagasan dan tidak mengubah gagasan terhadap kritikan yang diberikan, optimis akan kebenaran jawaban yang diperoleh dan tidak mudah dipengaruhi oleh orang lain.

Apek Ketekunan, Subjek sangat memiliki kesungguhan dalam belajar, selalu terdorong mengikuti bimbingan belajar disekolah maupun diluar sekolah, selalu mengikuti bimbingan olimpiade dibidang matematika, berlatih terus- menerus dalam menyelesaikan masalah-masalah matematika yang terdapat dibuku, tekun menyelesaikan masalah matematika yang bervariatif, tekun dan selalu meluangkan waktu dalam mengerjakan tugas sekolah maupun dirumah, selalu terpikirkan dan merasa bersalah jika bekum mengerjakan tugas dirumah, tidak cepat putus asa dalam mencapai tujuan.

Aspek Fleksibel, Subjek cenderung memiliki kemampuan untuk menemukan atau menghasilkan berbagai macam ide, jawaban serta pertanyaan yang bervariasi, sering menyelesaikan masalah matematika lebih dari satu cara penyelesaian, selalu memiliki jawaban yang bervariasi dalam mengerjakan soal-soal matematika yang sulit, selalu beker-jasa$\mathrm{ma} /$ berbagi pengetahuan dalam berdiskusi, cenderung sering mempunyai tanggapan yang berbeda dari orang lain, selalu menghargai pendapat orang lain dan mempertimbangkan sebelum mengambil keputusan.

Factor-faktor yang mempengaruhi disposisi matematis khususnya lingkungan sekolah Lingkungan sekolah subjek kedua sangat menerapkan disiplin sekolah serta menfasilitasi subjek ini dengan bimbingan belajar khususnya bimbingan olimpiade dan mengakarantinakan subjek disekolah agar lebih maksimal dalam belajarnya. Faktor kedua adalah lingkungan keluarga, Kedua subjek memiliki suasana rumah yang hening dan tenang sehingga kedua subjek diberi ketenangan kepada subjek dalam belajarnya dan keadaan ekonomi kedua subjek tergolong diatas rata-rata sehingga subjek terpenuhi kebutuhan pokok belajarnya selain itu hal terpenting sangat dipengaruhi oleh orang tua subjek yang sering diberi motivasi kepada subjek untuk tetap belajar, dan memperhatikan sama sekali akan kepentingan-kepentingan dan kebutuhan-kebutuhan belajarnya sehingga subjek pemenang olimpiade ini disposisinya lebih baik dan bisa berprestasi di dalam bidang pendidikan.

Mengacu kepada deskripsi pembahasan hasil penelitian dan kesimpulan di atas maka berikut akan dikemukakan beberapa saran antara lain: Hasil penelitian ini diharapkan dapat menjadi rekomendasi bagi para guru untuk memfasilitasi kegiatan-kegiatan yang mengarah pada disposisi matematis siswa dalam bidang ilmu pengetahuan dan teknologi melalui berbagai lomba, baik yang berskala nasional maupun internasional. Hasil penelitian ini diharapkan dapat menjadi sumber informasi untuk para 
siswa-siswa bahwa sikap disposisi matematis siswa yang kuat dan yang baik akan berperan dalam menumbuhkan dorongan untuk terus mencoba sehingga menghasilkan pribadi yang ulet sehingga dapat bersaing di dalam ajang olimpiade matematika.

\section{DAFTAR RUJUKAN}

Ardiyanto, Doni Setiyo. 2013. Pembelajaran matematika dengan pendekatan Kontekstual berbantuan hands on problem Solving untuk meningkatkan rasa ingin tahu dan Prestasi belajar siswa.Makalah jurusan pendidikan matematika FMIPA UNY

Departemen Pendidikan Nasional. 2008. Kamus Besar Bahasa Indonesia, Edisi keempat. Jakarta: Gramedia.

Elo, S \& Helvi Kyngas. 2007. The Qualitative Content Analysis Process. Journal of Advanced Nursing, 62(1), 107-115.

Graneheim, U.H. \& B. Lundman. 2003.

Quantitative Content Analysis in Nursing

Research : Concepts, Procedures and

Measures to Achives Trustworthiness.

Nurse Education today.24, 105-112.

Gresalfi. 2009.Taking Up Opportunities to Learn: Constructing Dispositions in Mathematics

Classrooms.http://www.tandfonline.com/l oi/hlns20. Diakses september 2014.

Katz, L. G. (2009). Dispositions as Educational Goals.

http://www.edpsycinteractive.org/files/edo utcomes.html.Diakses september 2014.

Kemendikbud. 2013. Kurikulum 2013. http://kemdikbud.go.id/kemdikbud/artikel -mendikbud-kurikulum2013.Diakses oktober 2014.

Kusumaningrum \& Saefudin.2012. Mengoptimalkan Kemampuan Berpikir Matematika melalui Pemecahan Masalah Matematika.Seminar nasional matematika \& pendidikan matematika FMIPA UNY.

Martyanti, Adhetia. 2012. Membangun selfcofidence siswa Dalam pembelajaran matematika dengan pendekatanproblem solving.Makalah jurusan pendidikan matematika FMIPA UNY

Maxwell, K. (2001). Positive Learning Dispositions in
Mathematics.www.education.auckland.ac. nz/.../ACE_Paper_3_Issue_11. doc. Diakses September 2014.

Pearson Education.(2000). Mathematical Disposition.

http://www.teachervision.fen.com/math/te acher-training/55328.html?

for_printing=1.Diakses september 2014

Polking J. (1998). Respon To NCTM's Round 4 Questions.

http://www.ams.org/goverment/argrpt4.ht ml. Diakses september 2014.

NCTM. 2007. The Mathematical Disposition of Structural Engineers.

Journal for Research in Mathematics Education, Vol. 38, No. 5 (Nov., 2007), pp.

477 -

506.http://www.jstor.org/stable/30034962.

Diakses september 2014

Slameto. 2010. Belajar dan Faktor-faktor yang Mempengaruhinya. Jakarta: Rineka Cipta.

Sugiyono, 2012.Memahami Penelitian Kualitatif. Bandung: PT Alfa Beta.

Sumarmo.Utari.2013. Kumpulan Makalah Berpikir dan Disposisi Matematika serta Pembelajarannya.Bandung : Jurusan Pendidikan Matematika FMIPA Universitas Pendidikan Indonesia.

Undang-undang Republik Indonesia Nomor 20 tahun 2003 tentang Sistem Pendidikan Nasional-UUSPN 